\title{
HUBUNGAN KARAKTERISTIK DAN PENGETAHUAN PERAWAT DALAM PENERAPAN SASARAN KESELAMATAN PASIEN
}

\author{
Fara Diba Salsabila Harahap \\ Email : salsabilaharahapfaradiba@ gmail.com
}

\section{Latar Belakang}

Keselamatan (safety) telah menjadi isu global termasuk juga untuk rumah sakit. Menurut Nursalam (2011:307), Keselamatan pasien (patient safety) merupakan suatu variabel untuk mengukur dan mengevaluasi kualitas pelayanan keperawatan yang berdampak terhadap pelayanan kesehatan.

Tuntutan dalam memenuhi semua standar pelayanan kesehatan termasuk pelayanan keperawatan yang profesional dengan standar internasional sudah didepan mata tidak lagi hanya berfokus pada kepuasan pasien tetapi lebih penting lagi adalah keselamatan pasien (patient safety). Harapan pelayanan profesional yang bermutu tinggi yang berfokus pada keselamatan (safety) dan kepuasan pasien dapat terlaksana (Setyarini EA, 2013) Oleh karena itu, keselamatan pasien merupakan prioritas utama untuk dilaksanakan di rumah sakit dan hal itu terkait dengan isu mutu dan citra rumah sakit.
Keberhasilan penerapan patient safety dapat dicapai apabila perawat mengetahui dengan tepat sesuatu yang mengancam keselamatan pasien selama perawatan di rumah sakit. Pengetahuan yang baik akan mempengaruhi perilaku perawat dalam memberikan asuhan keperawatan dengan tetap memprioritaskan keselamatan pasien. Menurut Achterbergh (2002), pengetahuan adalah informasi yang dapat mengubah seseorang untuk bertindak melakukan tindakan yang berbeda atau bertindak lebih efektif.

Tenaga perawat merupakan tenaga profesional yang berperan penting dalam fungsi di rumah sakit. Setiap tindakan medis menyimpan potensi resiko, banyaknya jenis obat, jenis pemeriksaan dan prosedur, serta jumlah pasien dan staf Rumah Sakit yang cukup besar terutama untuk tenaga perawat. Penerapan keselamatan pasien dapat diwujudkan dengan menetapkan standar, sasaran dan langkah menuju keselamatan pasien dengan tujuan akhir yaitu memberikan 
asuhan pasien yang lebih aman

(KEMENKES RI, 2017a).

Sasaran Keselamatan Pasien (SKP) menjadi indikator standar dasar yang utama dalam penilaian Akreditasi Rumah Sakit versi 2012 (KARS, 2013). Maksud dari sasaran keselamatan pasien adalah mendorong perbaikan spesifik dalam keselamatan pasien yang menyoroti bidang-bidang bermasalah dalam perawatan kesehatan, memberikan bukti dan solusi hasil konsensus yang berdasarkan nasihat para pakar.

\section{Metode}

Metode yang digunakan dalam penulisan ini yaitu menggunakan literature riview atau studi pustaka berdasarkan teks book, jurnal dan berfokus pada Hubungan karakteristik dan pengetahuan perawat dalam penerapan sasaran keselamatan pasien. Dengan cara menganalisis, eksplorasi sumber dan kajian bebas. Adapun sumber kajian yang digunakan ialah 10 tahun terakhir.

Dapat dikatakan pula jurnal ini menggunakan metode penelitian deskriptif. Metode deskriptif dapat menyelesaikan masalah dengan menganalisa, membandingkan, dan mendeskripsikan langkah-langkah menetukan diagnosa keperawatan melalui pendokumentasian yang tepat.
Hasil

Berdasarkan dari hasil literature review, Bahwa adanya hubungan karakteristik dan pengetahuan perawat dalam menerapkan sasaran keselamatan pasien. Karakteristik ini dipengaruhi juga oleh pengetahuan, pengalaman bekerja, umur, dan jenis kelamin.

Kemudian pengetahuan yang baik akan mempengaruhi perilaku perawat dalam memberikan asuhan keperawatan dengan tetap memprioritaskan keselamatan pasien. Maksud dari sasaran keselamatan pasien adalah mendorong perbaikan spesifik dalam keselamatan pasien yang menyoroti bidang-bidang bermasalah dalam perawatan kesehatan, memberikan bukti dan solusi hasil konsensus yang berdasarkan nasihat para pakar.

Pemenuhan kebutuhan kepuasan pasien selama di rumah sakit diperlukan tenaga kesehatan yang harus mempunyai pengetahuan (knowledge), keterampilan (skill) yang tinggi serta mempunyai sikap profesional (attitude) dan dapat menunjang pembangunan kesehatan. Upaya penerapan patient safety sangat tergantung dari pengetahuan perawat. Apabila perawat menerapkan patient safety didasari oleh pengetahuan yang memadai, maka perilaku patient safety oleh perawat 
tersebut akan bersifat langgeng (long lasting).

Ada enam sasaran keselamatan pasien yaitu : Ketepatan identifikasi pasien; Peningkatan komunikasi yang efektif; Peningkatan keamanan obat yang perlu diwaspadai; Kepastian tepatlokasi, tepatprosedur, tepat-pasien operasi; Pengurangan risiko infeksi terkait pelayanan kesehatan; dan Pengurangan risiko pasien jatuh (Permenkes Nomor 1691, 2011).

\section{Pembahasan}

Keselamatan (safety) menjadi isu global termasuk di rumah sakit. Rumah sakit wajib mengupayakan pemenuhan sasaran keselamatan pasien yang diatur dalam Peraturan Menteri Kesehatan nomor 11 tahun 2017. Keselamatan pasien (patient safety) adalah suatu sistem dimana rumah sakit membuat asuhan pasien lebih aman, mencegah terjadinya cidera yang disebabkan oleh kesalahan akibat melaksanakan suatu tindakan atau tidak mengambil tindakan yang seharusnya diambil. Sistem tersebut meliputi pengenalan resiko, identifikasi dan pengelolaan hal yang berhubungan dengan resiko pasien, pelaporan dan analisis insiden, kemampuan belajar dari insiden, tindak lanjut dan implementasi solusi untuk meminimalkan resiko.
Tenaga perawat merupakan tenaga profesional yang berperan penting dalam fungsi rumah sakit. Hal tersebut didasarkan atas jumlah tenaga perawat sebagai porsi terbesar didalam pelayanan rumah sakit. Dalam menjalankan fungsinya, perawat merupakan staf yang memiliki kontak terbanyak dengan pasien. Perawat juga merupakan bagian dari suatu tim, yang didalamnya terdapat berbagai profesional lain seperti dokter. Luasnya peran perawat memungkinkannya terjadinya risiko kesalahan pelayanan. Halhal tersebut menempatkan peran perawat sebagai komponen penting dalam pelaporan kesalahan pelayanan dalam pengembangan program keselamatan pasien di rumah sakit.

Maka dari itu upaya penerapan patient safety sangat tergantung dari pengetahuan perawat. Apabila perawat menerapkan patient safety didasari oleh pengetahuan yang memadai, maka perilaku patient safety oleh perawat tersebut akan bersifat langgeng (long lasting). Seorang perawat dalam memberikan asuhan keperawatan harus memiliki pengetahuan yang benar, keterampilan, dan sikap untuk menangani kompleksitas perawatan kesehatan. Tanpa pengetahuan yang memadai, tenaga kesehatan termasuk perawat tidak bisa 
menerapkan dan mempertahankan budaya keselamatan pasien (Myers, 2012, p.164).

Pemenuhan kebutuhan kepuasan pasien selama di rumah sakit diperlukan tenaga kesehatan yang harus mempunyai pengetahuan (knowledge), keterampilan (skill) yang tinggi serta mempunyai sikap profesional (attitude) dan dapat menunjang pembangunan kesehatan.

Menurut Surani (2008), pelatihan merupakan serangkaian aktivitas yang dirancang untuk meningkatkan pengetahuan, kemampuan, ketrampilan, sikap dan kinerja sumber daya manusia. Menurut Sukiarko (2007), pelatihan untuk meningkatkan pengetahuan dan keterampilan sebagai kriteria keberhasilan program kesehatan secara keseluruhan. Banyaknya pelatihan yang diikuti perawat bisa menjadi pengaruh yang kuat dalam menentukan baik tidaknya perawat dalam implementasi sasaran keselamatan pasien.

Hal yang dapat menyebabkan kecelakaan pasien adalah :

a) Kesalahan dalam mengidentifikasi pasien.

b) Komunikasi yang tidak efektif.

c) Penggunaan obat high alert yang tidak aman.

d) Tidak tepat lokasi, prosedur, dan pasien operasi.

e) Pencegahan risiko infeksi yang buruk. f) Pencegahan pasien jatuh yang buruk

Ada enam sasaran keselamatan pasien menurut (Permenkes Nomor 1691, 2011), yaitu :

1) Ketepatan identifikasi pasien.

2) Peningkatan komunikasi yang efektif.

3) Peningkatan keamanan obat yang perlu diwaspadai.

4) Kepastian tepatlokasi, tepat-prosedur, tepat-pasien operasi.

5) Pengurangan risiko infeksi terkait pelayanan kesehatan.

6) Pengurangan risiko pasien jatuh.

Rosyidah (2008), menyatakan bahwa kemahiran seseorang dalam mengimplementasikan sebuah tugas atau pekerjaannya tergantung pada tingkat pendidikan, pengetahuan dan pengalaman seseorang. Perawat yang tidak melaksanakan tugasnya dalam menjaga keselamatan pasien dari insiden keselamatan pasien, berarti menggambarkan perawat tersebut tidak amanah dalam melaksanakan tugas.

Karakteristik dari perawat terdiri dari kemampuan dan ketrampilan fisik dan mental dari individu sebagai perawat. Karakteristik ini dipengaruhi juga oleh :

a) Tingkat Pendidikan

Hughes (2008), mengatakan bahwa tingkat pendidikan merupakan salah satu 
karakteristik individu yang dapat meningkatkan pengetahuan perawat untuk dapat menerapkan patient safety (Yulia, Sri, 2012), sehingga dapat menurunkan angka kejadian tidak diharapkan (KTD). Pendidikan merupakan sebuah proses pengubahan sikap dan tingkah laku melalui pengajaran dan pelatihan formal maupun non formal yang pada akhirnya akan menghasilkan pengetahuan (Notoatmodjo, 2010). Perlu adanya jenis tenaga perawat berpendidikan lebih tinggi untuk meningkatkan mutu pelayanan Keperawatan (WHO, 2015).

b) Lama Bekerja (Pengalaman Bekerja)

Menurut Harus (2015), lama kerja berkaitan dengan pengalaman kerja, dimana merupakan salah satu faktor kunci dalam keselamatan pasien di rumah sakit. (Ranupandojo, 2010) yang menyatakan bahwa lama kerja terkait dengan masa kerja, semakin lama seseorang bekerja pada suatu organisasi maka semakin berpengelaman orang tersebut sehingga kecakapan kerjanya semakin baik.

c) Jenis Kelamin

Laki-laki dan perempuan adalah sama dalam hal kemampuan belajar dan bertindak, daya ingat, kemampuan penalaran, kreativitas, dan kecerdasan. Meskipun beberapa peneliti masih percaya adanya perbedaan kreativitas, penalaran, dan kemampuan antara pria dan wanita (WHO, 2015).

d) Umur atau usia

Umur atau usia mempengaruhi daya tangkap dan pola pikir. Semakin tua semakin bijaksana dan tidak dapat mengajarkan kepandaian baru kepada orang yang sudah tua karena kemunduran fungsi fisik dan mental (WHO, 2015).

\section{Penutup}

Terdapat hubungan antara karakteristik dan pengetahuan perawat dengan penerapan sasaran keselamatan pasien, diketahui pula bahwa semakin tinggi tingkat pengetahuan perawat tentang sasaran keselamatan pasien maka penerapan sasaran keselamatan pasien dalam asuhan keperawatan semakin baik adalah benar. Seorang perawat dalam memberikan asuhan keperawatan harus memiliki pengetahuan yang benar, keterampilan, dan sikap untuk menangani kompleksitas perawatan kesehatan. Tanpa pengetahuan yang memadai, tenaga kesehatan termasuk perawat tidak bisa menerapkan dan mempertahankan budaya keselamatan pasien (Myers, 2012, p.164). Adapun karakteriskitik perawat dalam menerapkan sasaran keselamatan pasien dipenagruhi oleh pengetahuan, pengalaman bekerja, umur, dan jenis kelamin. 


\section{Daftra Pustaka}

Bawelle, S.C., Sinolungan, J.S.V., \& Hamel, R.S. (2013). Hubungan pengetahuan dan sikap perawat dengan pelaksanaaan keselamatan pasien. (patient safety) di ruang rawat inap RSUD Liun Kendage Tahuna. Ejournal Keperawatan (e-Kp), 1(1), 17.

Cahyono A. (2015). Hubungan Karakteristik dan Tingkat Pengetahuan Perawat Terhadap Pengelolaan Keselamatan Pasien di Rumah Sakit. Jurnal Ilmiah WIDYA. 3 (2), 97-102.

Darliana D. (2016). Hubungan Pengetahuan Perawat Dengan Upaya Penerapan Patient safety di Ruang Rawat Inap Rumah Sakit Umum Daerah DR.Zainoel Abidin Banda Aceh. Idea Nursing Journal. 7(1). ISSN : 2087-2879 61 .

Harus, B. D. A. S. (2015). Pengetahuan Perawat Tentang Keselamatan Pasien dengan Palaksanaan Prosedur Keselamatan Pasien Rumah Sakit Panti Waluyo Sawahan Malang. CARE, 3(1), 25-32.

Iswati. (2013). Penerapan Sasaran Keselamatan Pasien Di Rumah Sakit.
Akademi Keperawatan Adi Husada Hal. 59-63.

Kementerian Kesehatan R.I. (2011). Peraturan Menteri Kesehatan RI no 1691 tentang Keselamatan Pasien, Jakarta, Indonesia.

Neri R.A , Lestari Y, Yetti H. (2018) . Analasis Pelaksanaan Sasaran Keselamatan Pasien di Rawat Inap Rumah Sakit Umum Daerah Padang Pariaman. Jurnal Kesehatan Andalas. 7(4), 48-55.

Nursalam. (2011). Manajemen Keperawatan. Jakarta : Salemba.

Setiyani M. D, Zuhrotunida, Syahridal. (2016) . Implementasi sasaran keselamatan pasien di ruang rawat inap RSU Kabupaten Tanggerang. JKFT ; Edisi Nomor 2 , 59-69.

Simamora, R. H. (2018). Buku ajar keselamatan pasien melalui timbang terima pasien berbasis komunikasi efektif: SBAR. Medan: USUpress.

Simamora, R. H. (2020). Learning of Patient Identification in Patient Safety Programs Through Clinical Preceptor Models. Medico Legal Update, 20(3), 553-556.

Surahmat R , Neherta M , Nurariati. (2019). Hubungan Karakteristik 
Perawat terhadap Pelaksanaan Sasaran Keselamatan Pasien Pasca Akreditasi Rumah Sakit "X" di Kota Palembang Tahun 2018. jurnal Ilmiah Universitas Batanghari Jambi 19(1) ; 1-10. ISSN
1411-8939 (Online) | ISSN 2549-4236 (Print). 